\title{
Molecular dynamics of amphiphilic calixarene
}

\author{
Yuji Tokunaga,* Hiromasa Sakon, Hirokazu Kanefusa, \\ Youji Shimomura, and Kiyoshi Suzuki
}

\begin{abstract}
Department of Materials Science \& Engineering, Faculty of Engineering, Fukui University, Bunkyo, Fukui, 910-8507, Japan

E-mail: tokunaga@matse.fukui-u.ac.jp
\end{abstract}

Dedicated to Professor Keiichiro Fukumoto on his $70^{\text {th }}$ anniversary

(received 25 May 03; accepted 03 Aug 03; published on the web 06 Aug 03)

\begin{abstract}
An amphiphilic calix[6]arene, which possesses a deep cavity, aggregates in aqueous solution by hydrophobic interaction. The conformation of aggregated calix[6]arene is conical owing to the coordination of metal ions and hydrophobic interaction between its aromatic parts. Variable temperature NMR experiments reveal that the species of metal cations are able to control the stability of the aggregated supramolecular structure, and that its molecular dynamics are regulated by the concentration of salt. These results are valuable for molecular recognition using calixarene in aqueous systems.
\end{abstract}

Keywords: Calixarene, hydrophobic interaction, molecular recognition, self assembly

\section{Introduction}

Calixarenes possessing azobenzene units are interesting molecules owing to their unique properties. Chromogenic calixarenes which have metal-binding sites and coloration sites act as metal-selective receptors and sensors. ${ }^{1,2}$ The introduction of azobenzene gives calixarene a deep cavity which can include one large molecule or two guest molecules. ${ }^{3,4}$ The photochemical behavior of calix-resorcino-arenes with four azobenzene residues in solution and monolayers has been investigated. ${ }^{5,6}$ The solubility of calixarene was dramatically changed by trans- to cis- and cis- to trans- photoisomerization in solution, and reversible changes in the areas of calixarene monolayers were achieved by photoisomerization.

Water-soluble calixarene ${ }^{7}$ has received much research attention. For example, hexasulfonated calixarene efficiently accelerates acid-catalyzed hydration of 1,4dihydronicotinamide, ${ }^{8}$ regioselective cleavage of ribonucleoside 2 ',3'-cyclic phosphate, ${ }^{9}$ and acts as an artificial-signaling acetylcholine receptor in solution. ${ }^{10}$ Cationic water-soluble calixarenes also act as efficient catalytic hosts for the basic hydrolysis of esters, ${ }^{11,12}$ or as effective inverse- 
phase- transfer catalysts in the reaction of sodium cyanide in aqueous solution with a series of alkyl halides. ${ }^{13}$ Hayashida et al. synthesized a calixarene possessing numerous glucoses, which recognizes biologically important phosphates, such as nucleotides, via hydrogen bonding. ${ }^{14}$

We have been interested in the possibility of developing a water-soluble calixarene possessing azobenzenes into a sensor for biologically important compounds, and in the creation of photo-responsive materials. During related experiments, the aggregative behavior of calixarene in water was discovered, and here we wish to report that several species of metal cation are able to control the stability of the aggregated structure, and that its molecular dynamics are regulated by the concentration of sodium chloride.

\section{Results and Discussion}

The key compound, azo-calix[6]arene 2a was prepared by diazo-coupling ${ }^{1,2,3,15}$ of calix[6]arene $\mathbf{1}^{16}$ with a 3-carboxybenzenediazonium cation (Scheme 1). The ${ }^{1} \mathrm{H}$ NMR spectrum of azocalix[6]arene 2a in DMSO- $\mathrm{d}_{6}$ is shown in Figure 1a. The chemical shifts and coupling patterns of all signals in the NMR spectrum match the putative characteristics of the molecule: the five signals from the aromatic protons of calixarene 2a can be assigned, and aliphatic protons are observed as a broad signal around $\delta 4.02 \mathrm{ppm}$. The observations show that the oxygen-throughannulus rotation ${ }^{17}$ of the aromatic parts of calixarene is fast on the NMR time scale in DMSO- $\mathrm{d}_{6}$ at $30{ }^{\circ} \mathrm{C}$. On the other hand, broad signals representing aromatic protons and two doublet resonances $(J=15 \mathrm{~Hz})$ are clearly observed in the ${ }^{1} \mathrm{H}$ NMR spectrum of $\mathbf{2 a}$ in $1.61 \mathrm{M} \mathrm{NaOD} / \mathrm{D}_{2} \mathrm{O}$ at the same temperature (Figure 1c). The observation of two sets of aliphatic signals suggests that the calixarene in $\mathrm{NaOD} / \mathrm{D}_{2} \mathrm{O}$ has a predominantly conical conformation: that is, six aromatic parts are arrayed facing in the same direction, and the ring inversion is slow on the NMR timescale.

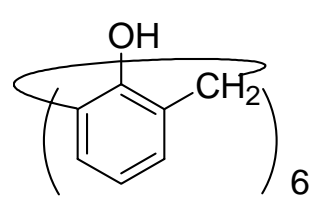

1

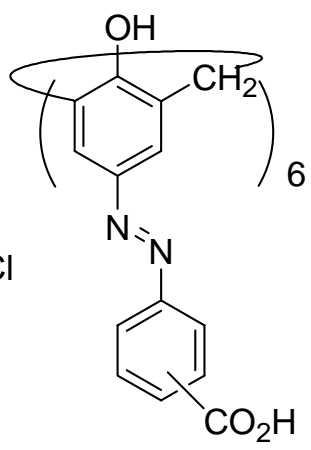

$2 \mathrm{a} 3-\mathrm{CO}_{2} \mathrm{H}$

2b $4-\mathrm{CO}_{2} \mathrm{H}$

\section{Scheme 1}



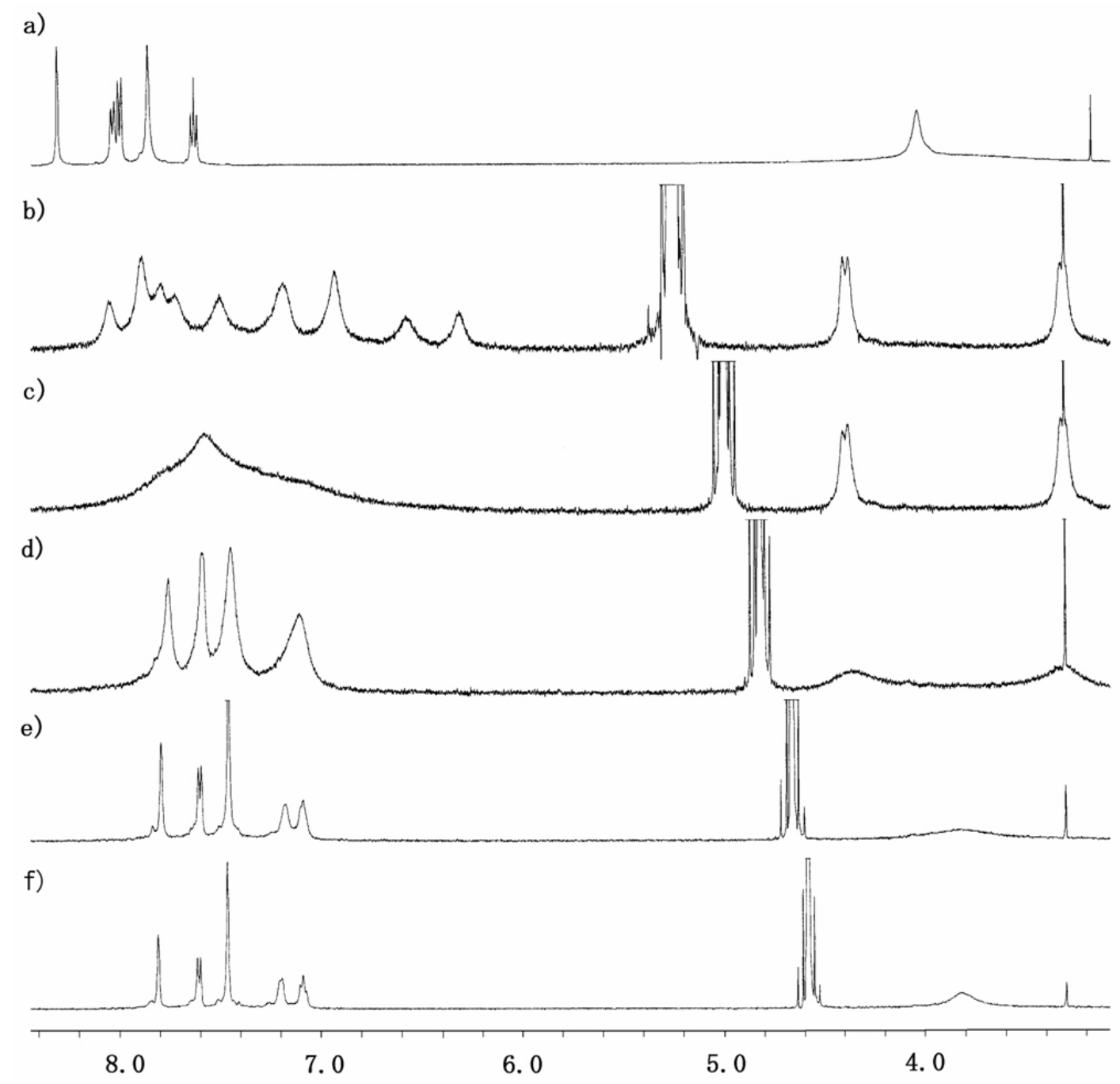

Figure 1. The ${ }^{1} \mathrm{H}$ NMR spectra of $2 \mathrm{a}$ recorded at $500 \mathrm{MHz}$. (a) $2 \mathrm{a}(5.0 \mathrm{mM})$ in DMSO- $\mathrm{d}_{6}$ at $30{ }^{\circ} \mathrm{C}$, (b) $2 \mathrm{a}(5.0 \mathrm{mM})$ in $\mathrm{NaOD} / \mathrm{D}_{2} \mathrm{O}(1.61 \mathrm{M})$ at $1{ }^{\circ} \mathrm{C}$, (c) 2a $(5.0 \mathrm{mM})$ in $\mathrm{NaOD} / \mathrm{D}_{2} \mathrm{O}(1.61 \mathrm{M})$ at $30{ }^{\circ} \mathrm{C}$, (d) $2 \mathrm{a}(5.0 \mathrm{mM})$ in $\mathrm{NaOD} / \mathrm{D}_{2} \mathrm{O}(1.61 \mathrm{M})$ at $50{ }^{\circ} \mathrm{C}$, (e) $2 \mathrm{a}(5.0 \mathrm{mM})$ in $\mathrm{NaOD} / \mathrm{D}_{2} \mathrm{O}(1.61$ $M)$ at $70{ }^{\circ} \mathrm{C}$, (f) 2a $(5.0 \mathrm{mM})$ in $\mathrm{NaOD} / \mathrm{D}_{2} \mathrm{O}(1.61 \mathrm{M})$ at $80{ }^{\circ} \mathrm{C}$, (g) 2a $(0.5 \mathrm{mM})$ in $\mathrm{NaOD} / \mathrm{D}_{2} \mathrm{O}$ $(0.161 \mathrm{M})$ at $25^{\circ} \mathrm{C}$, and $(\mathrm{g}) 2 \mathrm{a}(0.05 \mathrm{mM})$ in $\mathrm{NaOD} / \mathrm{D}_{2} \mathrm{O}(16 \mathrm{mM})$ at $25^{\circ} \mathrm{C}$. The product included $1 / 5$ equivalent of methanol, which was determined by ${ }^{1} \mathrm{H}$ NMR integration. The methyl resonance of methanol was used as the standard ( $\delta 3.30 \mathrm{ppm})$.

The temperature-dependent evolution of the spectra of $\mathbf{2 a}$ in $1.61 \mathrm{M} \mathrm{NaOD} / \mathrm{D}_{2} \mathrm{O}$ is shown in Figures $1 \mathrm{~b}-\mathrm{f}$. At $1{ }^{\circ} \mathrm{C}$, new resonances attributable to aromatic protons appear in the high field region $(6.2-7.3 \mathrm{ppm})$. In the range of $1-30{ }^{\circ} \mathrm{C}$, all resonances assigned to aromatic protons are broadened at elevated temperatures. Also, above $30{ }^{\circ} \mathrm{C}$, the signals for aliphatic protons at $\delta 3.31$ and 4.39 broadened, eventually overlapping at $>60{ }^{\circ} \mathrm{C}$, but the signals of the aromatic protons separated, as seen in the spectrum of 2a in DMSO- $\mathrm{d}_{6}$. From these experiments, the coalescence temperature $\left(\mathrm{T}_{\mathrm{c}}\right)$ of the aliphatic protons and the free energy of activation $\left(\Delta \mathrm{G}^{\neq}\right)$were estimated (Table 1, run 1). When the isomer $p$-(4-carboxyphenylazophenyl)calix[6] arene $\mathbf{2 b}$, was prepared 
in a similar manner, the VT NMR spectra of $\mathbf{2 b}$ afforded similar results $\left(\mathrm{T}_{\mathrm{c}}=58{ }^{\circ} \mathrm{C}\right)$. The ${ }^{1} \mathrm{H}$ NMR spectra of low concentrations of $2 \mathbf{a}$ in $\mathrm{NaOD} / \mathrm{D}_{2} \mathrm{O}$ at $25^{\circ} \mathrm{C}$ are shown in Figures $1 \mathrm{~g}$ and $\mathrm{h}$. With dilution of 2a and $\mathrm{NaOD}$, the signals for the aromatic protons separated, and those for aliphatic protons broadened, as seen in the spectra of a $5.0 \mathrm{mM}$ solution of $2 \mathbf{a}$ at high temperatures.

When viewed together, these observations lead us to conclude that the ring inversion and aggregation processes occur slowly at low temperatures, and that the high-field-shifted resonances $\left(\delta 6.2-7.3 \mathrm{ppm}\right.$ at $\left.1{ }^{\circ} \mathrm{C}\right)$ may be attributed to the hydrophobic interaction between the aromatic parts of calixarenes, which causes the 2a-form oligomer in aqueous solution. Integrations of the high-field-shifted resonances show the lower-order oligomer to form predominantly in aqueous solution. With increasing temperature, the reversible aggregation process and the rotation of the aromatic parts simultaneously speed up on the NMR time scale (Figure 2). In addition, the concentration-dependant NMR shows that 2a predominantly exists as a monomeric form in $\mathrm{NaOD} / \mathrm{D}_{2} \mathrm{O}$ at low concentrations, in contrast, aggregated complexes are favorable at high concentrations (Figure 2). To confirm the interpretation, NMR titration was performed. As shown in Figure 3 b, 2a $(5.0 \mathrm{mM})$ in $\mathrm{NaOD} / \mathrm{D}_{2} \mathrm{O}$ at $30{ }^{\circ} \mathrm{C}$ produces broad signals in the NMR spectrum. On the addition of suitable guest, 1-adamantyl-trimethylammonium iodide $\left(\mathrm{Ad}-\mathrm{N}^{+} \mathrm{Me}_{3}\right.$ ), sharp and clearly resolved signals, assigned to calixarene, are obtained, and a set of upfield signals corresponding to protons in $\mathrm{Ad}-\mathrm{N}^{+} \mathrm{Me}_{3}$ emerges (Figure 3c-e). The broad signals appearing upfield indicates that the guest is in an environment shielded by aromatic ring current. The rate of association-dissociation is fast on the NMR time scale, time averaged signals can be seen when binding occurs. Interestingly, the change of aliphatic protons of 2a can be hardly observed during the addition of $\mathrm{Ad}-\mathrm{N}^{+} \mathrm{Me}_{3}$. It is most likely that the observations show that competitive molecular recognition proceeds between intermolecular aggregates and host-guest complex, and that both complexes predominantly have a cone conformation (Figure 2).

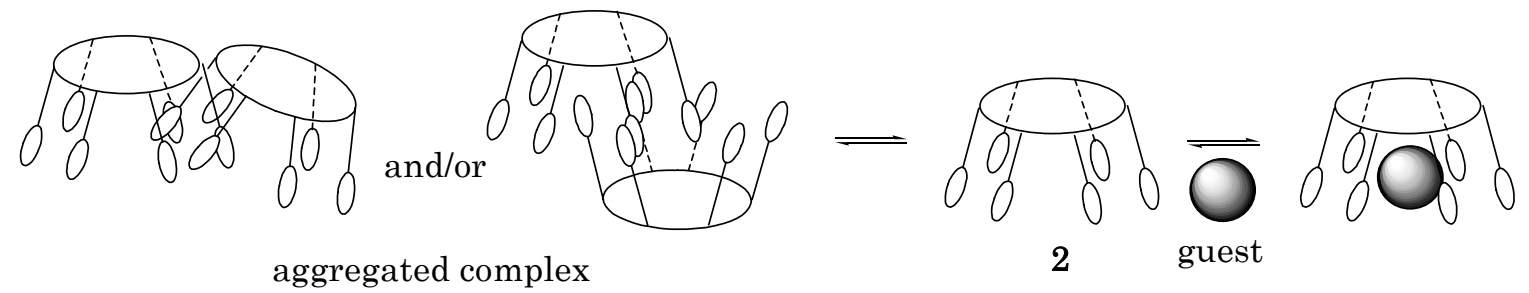

\section{Figure 2}

Next, to investigate the effect of additives on the molecular dynamics, we performed a VT NMR experiment on 2a in $\mathrm{D}_{2} \mathrm{O}$ in the presence of other alkali metal ions: potassium, rubidium, and cesium, shown in Table 1, runs 3-5. Although it has been reported that cesium ions have the most suitable radius for the cavity of cone conformation of calix[6]arene, ${ }^{18,19}$ the $\Delta \mathrm{G}^{\neq}$value for aggregation of $2 \mathbf{a}$ in $\mathrm{NaOD} / \mathrm{D}_{2} \mathrm{O}$ was the highest in our results, suggesting that the cavity of the cone conformer rarely includes two sodium ions in $\mathrm{CDCl}_{3}$ because of cation-cation interaction. 
However, it is extremely likely that two sodium ions in the cavity are stabilized, owing to phenoxy anions and the polar solvent in basic aqueous solution, because the conformation of 2a in $\mathrm{D}_{2} \mathrm{O}$ in the presence of sodium carbonate, a weak base, could not anchor within the cone. Potassium and rubidium ions are cases of, "too much or too little" with respect to the cavity.

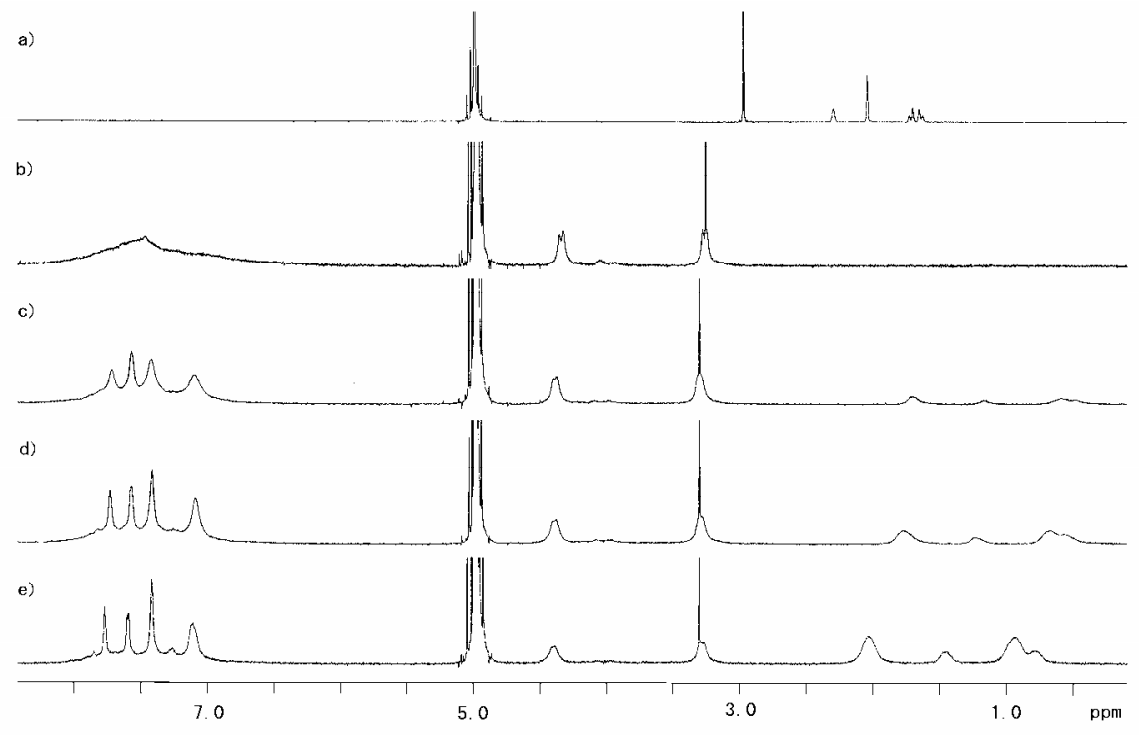

Figure 3. The $1 \mathrm{H}$ NMR spectra of $\mathbf{2 a}, \mathrm{AdN}^{+} \mathrm{Me}_{3}$, and mixtures of $\mathbf{2 a}$ and $\mathrm{AdN}^{+} \mathrm{Me}_{3}$ recorded at $500 \mathrm{MHz}$ in $\mathrm{NaOD} / \mathrm{D}_{2} \mathrm{O}(1.61 \mathrm{M})$ at $30{ }^{\circ} \mathrm{C}$. (a) $\mathrm{AdN}^{+} \mathrm{Me}_{3}$, (b) 2a, (c) a 2:1 mixture of 2a $(5.0$ $\mathrm{mM})$ and $\mathrm{AdN}^{+} \mathrm{Me}_{3}(2.5 \mathrm{mM})$, (d) a 1:1 mixture of $2 \mathrm{a}(5.0 \mathrm{mM})$ and $\mathrm{AdN}^{+} \mathrm{Me}_{3}(5.0 \mathrm{mM})$, (e) a $1: 2$ mixture of $2 \mathbf{a}(2.5 \mathrm{mM})$ and $\mathrm{AdN}^{+} \mathrm{Me}_{3}(5.0 \mathrm{mM})$.

To study the molecular behavior of the present host system in more detail, the coalescence temperatures of the aliphatic protons were investigated in the presence of varying amounts of sodium deuteroxide and sodium chloride. The coalescence temperatures of the aliphatic protons decreased with increasingly dilute sodium deuteroxide (runs 1, 2, and 6) and increased with increasing concentrations of sodium chloride (runs 7-12). Moreover, the observation of similar shapes of resonance for aromatic protons in all NMR spectra at coalescence temperatures shows that the rate of reversible aggregation is parallel to that of rotation. This evidence suggests two possibilities: (1) the stabilization of the cone conformation by sodium ion causes 2 to aggregate; and (2) the salt effect promotes hydrophobic interaction to form a more stable aggregated complex. Since it has been reported that the presence of cesium ions raises the coalescence temperature of aliphatic protons of calix[6]arene, ${ }^{21}$ and that the azo-calix[4]arene $3^{3}$ and hexasulfonated calix[6]arene $4^{8}$ do not form a strong aggregated complex in aqueous solution at ambient temperature (Figure 4), both effects may act cooperatively. The aggregation of calixarene obtained by self-assembly via self-inclusion has been reported by a few groups; however, the intermolecular weak interactions between the cavity and alkyl- or aryl residues present at the edge of calixarene contributed to the supramolecular structures in all cases. ${ }^{82-25}$ 
Owing to the large cavity size and the deep hydrophobic pocket, calixarene 2, which has no alkyl or aryl residues at its ends, can form an associated complex.

Table 1. Tc, $\Delta v$ and $\Delta \mathrm{G}^{\neq}$values for aggregation of calixarene $2 \mathrm{a}$ in $\mathrm{D}_{2} \mathrm{O}^{\mathrm{a}}$

\begin{tabular}{ccccc}
\hline Run & Additive & $\mathrm{T}_{\mathrm{c}}\left({ }^{\circ} \mathrm{C}\right.$ & $(\mathrm{Hz})$ & $\Delta \mathrm{G}^{\neq}(\mathrm{kJ} / \mathrm{mol})$ \\
\hline 1 & $1.61 M \mathrm{NaOD}$ & 60 & $541^{\mathrm{c}}$ & 62.2 \\
2 & $0.54 M \mathrm{NaOD}$ & 47 & $531^{\mathrm{d}}$ & 59.7 \\
3 & $0.54 M \mathrm{KOD}$ & 40 & $516^{\mathrm{e}}$ & 58.4 \\
4 & $0.54 M \mathrm{RbOD}$ & 34 & $529^{\mathrm{e}}$ & 57.2 \\
5 & $0.54 M \mathrm{CsOD}$ & 46 & $552^{\mathrm{e}}$ & 59.4 \\
6 & $0.27 M \mathrm{NaOD}$ & 37 & $526^{\mathrm{e}}$ & 57.8 \\
7 & $0.27 M \mathrm{NaOD}+0.27 M \mathrm{NaC}$ & 44 & $528^{\mathrm{e}}$ & 59.1 \\
8 & $0.27 M \mathrm{NaOD}+0.54 M \mathrm{NaC}$ & 47 & $529^{\mathrm{e}}$ & 59.7 \\
9 & $0.27 M \mathrm{NaOD}+0.80 M \mathrm{NaC}$ & 51 & $533^{\mathrm{e}}$ & 60.5 \\
10 & $0.27 M \mathrm{NaOD}+1.07 M \mathrm{NaC}$ & 53 & $539^{\mathrm{e}}$ & 60.8 \\
11 & $0.27 M \mathrm{NaOD}+1.34 M \mathrm{NaC}$ & 56 & $543^{\mathrm{e}}$ & 61.4 \\
12 & $0.27 M \mathrm{NaOD}+1.61 M \mathrm{NaC}$ & 58 & $545^{\mathrm{e}}$ & 61.8 \\
\hline
\end{tabular}

${ }^{\mathrm{a}}$ All NMR experiments were performed at a calixarene 2a concentration of $5 \mathrm{mM} .{ }^{\mathrm{b}}$ Estimated using the coalescence method. ${ }^{20}$ Rate constants for rotation of the aromatic parts $\left(\mathrm{k}_{\mathrm{c}}\right)$ at the coalescence temperature $\left(\mathrm{T}_{\mathrm{c}}\right)$ were evaluated by employing the approximate expression $\mathrm{k}_{\mathrm{c}}=$ $\pi(\Delta v) / 2^{1 / 2}$, where $\Delta v$ is the chemical shift difference between coalescing signals in the absence of any exchange. The relationship $\Delta \mathrm{G}^{\neq}=-\mathrm{RT}_{\mathrm{c}} \ln \left(\mathrm{k}_{\mathrm{c}} \mathrm{h} / \mathrm{k}_{\mathrm{B}} \mathrm{T}_{\mathrm{c}}\right)$, where $\mathrm{R}, \mathrm{h}$, and $\mathrm{k}_{\mathrm{B}}$ correspond, respectively, to the gas-, Planck-, and Boltzmann constants, was used to obtain values for the free energy of activation for aggregation $\left(\Delta \mathrm{G}^{\neq}\right)$at $\mathrm{T}_{\mathrm{c}}$. The $\Delta v$ values were measured at $30{ }^{\circ} \mathrm{C}^{\mathrm{c}}$, at $10^{\circ} \mathrm{C}^{\mathrm{d}}$, and at $1{ }^{\circ} \mathrm{C}^{\mathrm{e}}$.
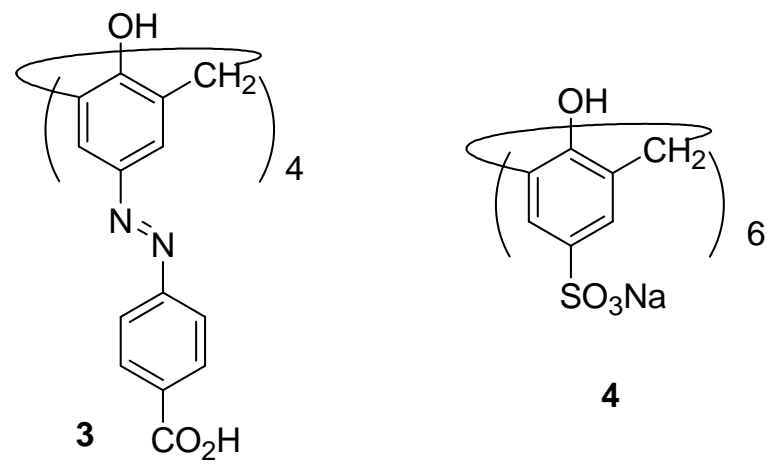

4

\section{Figure 4}




\section{Conclusions}

Amphiphilic calixarene molecules recognize each other and form oligomeric complexes in aqueous solution owing to hydrophobic interaction, and the large cavity size and deep hydrophobic cavity are important factors that allow the calixarenes to aggregate. The results of VT NMR experiments indicate that the species and concentration of metal ions play important roles in regulating calixarenes' molecular dynamics.

\section{Experimental Section}

General Procedures. Melting points were determined using a YAMATO Scientific melting point apparatus equipped with a digital thermometer. ${ }^{1} \mathrm{H}$ - and ${ }^{13} \mathrm{C}$ - NMR spectra were recorded on a JEOL LA-500 spectrometer (500- and $125 \mathrm{MHz}$, respectively). All reagents were of reagent grade and were used without purification. IR spectra were determined on a JASCO A-202 instrument.

p-Hexakis-(3-carboxyphenylazo)calix[6]arene (2a). To a magnetically stirred suspension of 3aminobenzoic acid $(0.75 \mathrm{~g}, 5.50 \mathrm{mmol})$ and $37 \%$ aqueous $\mathrm{HCl}(0.86 \mathrm{ml}, 240 \mathrm{mmol})$ in $\mathrm{H}_{2} \mathrm{O}$ was added a solution of sodium nitrite $(0.38 \mathrm{~g}, 5.50 \mathrm{mmol})$ in water $(10 \mathrm{ml})$ at $0{ }^{\circ} \mathrm{C}$ and stirred for 30 $\min$. This reaction mixture was added under ice-cooling to a solution of calix[6]arene $1(0.50 \mathrm{~g}$, $0.79 \mathrm{mmol})$ in pyridine $(3.60 \mathrm{~g}, 4.70 \mathrm{mmol})$ and THF $(5 \mathrm{ml})$. The mixture was stirred during $2 \mathrm{~h}$, then THF was removed under reduced pressure. To the residue was added $10 \%$ aqueous $\mathrm{HCl}$ until the $\mathrm{pH}$ reached 1 , and the precipitate was collected by filtration. The solid was washed with $\mathrm{H}_{2} \mathrm{O}$ and methanol, and dried. The calixarene 2a was obtained as a red powder (1.12 g, $93 \%) . \mathrm{mp}>220^{\circ} \mathrm{C}$. IR $v_{\max }(\mathrm{KBr}) / \mathrm{cm}^{-1}: 3050,3000,1700,1600,1270,1120,910 .{ }^{1} \mathrm{H}$ NMR $\left(500 \mathrm{MHz}, \mathrm{DMSO}_{6} \mathrm{~d}_{6}\right) \delta: 4.02$ (br. s, 12H), 7.69 (t, 6H, 7.6 Hz), 7.92 (s, 12H), 8.06 (br. d, 6H, $7.6 \mathrm{~Hz}$ ), 8.09 (br. d, 6H, $7.6 \mathrm{~Hz}$ ), 8.37 (br. s, $6 \mathrm{H}$ ). ${ }^{13} \mathrm{C}$ NMR (125 MHz, DMSO-d 6 ) $\delta: 31.60$, 121.62, 124.29, 126.29, 128.89, 129.42, 130.13, 131.87, 144.49, 151.76, 158.60, 166.62. Anal. Calcd. for $\mathrm{C}_{84} \mathrm{H}_{60} \mathrm{~N}_{12} \mathrm{O}_{18} .1 / 5 \mathrm{CH}_{3} \mathrm{OH} .6 \mathrm{H}_{2} \mathrm{O}: \mathrm{C}, 61.67 ; \mathrm{H}, 4.47 ; \mathrm{N}, 10.25$. Found. C, 61.89; H, $4.31 ; \mathrm{N}, 9.87 \%$.

p-Hexakis-(4-ethylcarboxyphenylazo)calix[6]arene. Calix[6]arene $1(1.00 \mathrm{~g}, 1.57 \mathrm{mmol})$ and ethyl 4-aminobenzoate $(1.82 \mathrm{~g}, \quad 11.0 \mathrm{mmol}) \quad$ were used to obtain $p$-hexakis-(4ethoxycarbonylphenylazo)-calix[6]arene $(2.61 \mathrm{~g}, 98 \%) . \mathrm{mp}>220^{\circ} \mathrm{C}$. IR $v_{\max }(\mathrm{KBr}) / \mathrm{cm}^{-1}: 3440$, 2990, 1720, 1600, 1270, 1150, 1050. ${ }^{1} \mathrm{H}$ NMR (500 MHz, DMSO-d 6 ) $\delta 1.25$ (t, 18H, $7.0 \mathrm{~Hz}$ ), 4.06-4.09 (m, 12H), $4.42(\mathrm{q}, 12 \mathrm{H}, 7.0 \mathrm{~Hz}), 7.87(\mathrm{~s}, 12 \mathrm{H}), 7.92(\mathrm{~m}, 12 \mathrm{H}), 8.13(\mathrm{~m}, 12 \mathrm{H}) .{ }^{13} \mathrm{C}$ NMR $\left(125 \mathrm{MHz}, \mathrm{DMSO}_{-} \mathrm{d}_{6}\right)^{26} \delta 13.93,60.64,121.64,124.43,129.02,130.06,165.07$. Anal. Calcd. for $\mathrm{C}_{96} \mathrm{H}_{84} \mathrm{~N}_{12} \mathrm{O}_{18} .2 \mathrm{H}_{2} \mathrm{O}$ : C, 66.66; H, 5.13; N, 9.72. Found C, 66.39; H, 4.95; N, 9.49\%.

p-Hexakis-(4-carboxyphenylazo)calix[6]arene (2b). A solution of p-hexakis-(4ethoxycarbonyl-phenylazo)-calix[6]arene $(2.51 \mathrm{~g}, 1.48 \mathrm{mmol})$ and $\mathrm{NaOH}(2.00 \mathrm{~g}, 50 \mathrm{mmol})$ in 
water $(30 \mathrm{ml})$, methanol $(30 \mathrm{ml})$, and THF $(30 \mathrm{ml})$ was heated at $50{ }^{\circ} \mathrm{C}$ for $15 \mathrm{~h}$. After cooling, the THF and methanol were removed under reduced pressure. To the residue was added 10\% aqueous $\mathrm{HCl}$ until the $\mathrm{pH}$ reached 1, and the precipitate was collected by filtration. The solid was washed with $\mathrm{H}_{2} \mathrm{O}$ and methanol and dried. Thereby, the calix[6] arene $\mathbf{2 b}$ was obtained as a red powder $(2.18 \mathrm{~g}, 96 \%) \mathrm{mp}>220^{\circ} \mathrm{C}$. IR $v_{\max }(\mathrm{KBr}) / \mathrm{cm}^{-1}: 3100,1700,1610,1260,1120,1010$. ${ }^{1} \mathrm{H}$ NMR (500 MHz, DMSO-d 6 ) $\delta: ~ 4.13-4.20(\mathrm{~m}, 12 \mathrm{H}), 7.87(\mathrm{~s}, 12 \mathrm{H}), 7.90(\mathrm{~m}, 12 \mathrm{H}), 8.11(\mathrm{~m}$,

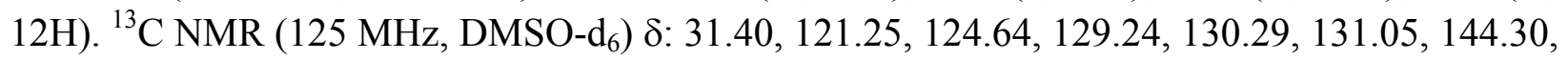
153.89, 160.00, 166.59. Anal. Calcd. for $\mathrm{C}_{84} \mathrm{H}_{60} \mathrm{~N}_{12} \mathrm{O}_{18} .9 .5 \mathrm{H}_{2} \mathrm{O}$ : C, 59.19; H, 4.39; N, 9.70. Found C, 59.47; H, 4.69; N, 9.91\%.

\section{Acknowledgments}

This research was supported by Fukui University.

\section{References and Notes}

1. Shimizu, H.; Iwamoto, K.; Fujimoto, K.; Shinkai, S. Chem. Lett. 1991, 2147.

2. Nomura, E.; Taniguchi, H.; Tamura, S. Chem. Lett. 1989, 1125.

3. Tyson, J. C.; Collard, D. M.; Hughes, K. D. J. Inclusion Phenom. Mol. Recognit. Chem. 1997, 29, 109.

4. For a recent review on deep cavity, see: Rudkevich, D. M. Bull. Chem. Soc. Jpn. 2002, 75, 393.

5. Tyson, J. C.; Moore, J. L.; Hughes, K. D.; Collard, D. M. Langmuir 1997, 13, 2068.

6. (a) Ichimura, K.; Fukushima, N.; Fujimaki, M.; Kawahara, S.; Matsuzawa, Y.; Hayashi, Y.; Kubo, K. Langmuir 1997, 13, 6780 (b). Fujimaki, M.; Matsuzawa, Y.; Hayashi, Y.; Ichimura, K. Chem. Lett. 1998, 165.

7. Gutsche, C. D; Alam, I. Tetrahedron 1988, 44, 4689.

8. Shinkai, S.; Mori, S.; Koreishi, H.; Tsubaki, T.; Manabe, O. J. Am. Chem. Soc. 1986, 108, 2409.

9. Komiyama, M.; Isaka, K.; Shinkai, S. Chem. Lett. 1991, 937.

10. Koh, K. N.; Araki, K.; Ikeda, A.; Otsuka, H.; Shinkai, S. J. Am. Chem. Soc. 1996, 118, 755.

11. Shinkai, S.; Shirahama, Y.; Tsubaki, T.; Manabe, O. J. Am. Chem. Soc. 1989, 111, 5477.

12. Shinkai, S.; Shirahama, Y.; Tsubaki, T.; Manabe, O. J. Chem. Soc., Perkin Trans. 1 1989, 1859.

13. Shimizu, S.; Kito, K.; Sasaki, Y.; Hirai, C. Chem. Commun. 1997, 1629.

14. Hayashida, O.; Kato, M.; Akagi, K.; Aoyama, Y. J. Am. Chem. Soc. 1999, 121, 11597. 
15. (a) Deligöz, H.; Ercan, N. Tetrahedron 2002, 58, 2881. (b). Shinkai, S.; Araki, K.; Shibata, J.; Tsugawa, D.; Manabe, O. J. Chem. Soc., Perkin Trans. 1 1990, 3333. (c). Morita, Y.; Agawa, T.; Nomura, E.; Taniguchi, H. J. Org. Chem. 1992, 57, 3658.

16. Gutsche, C. D.; Iqbal, M.; Stewart, D. J. Org. Chem. 1986, 51, 742.

17. (a) Gutsche, C. D.; Bauer, L. J. J. Am. Chem. Soc. 1985, 107, 6052. (b). Arimura, T.; Shinkai, S.; Matsuda, T.; Hirata, Y.; Sato, H.; Manabe, O. Bull. Chem. Soc. Jpn. 1988, 61, 3733.

18. (a) Ikeda, A.; Suzuki, Y.; Yoshimura, M. Shinkai, S. Tetrahedron 1998, 54, 2497. (b).Shinkai, S. J. Inclusion Phenom. Mol. Recognit. Chem. 1989, 7, 193.

19. Chang, S.-K.; Cho, I. J. Chem. Soc., Perkin Trans. 1 1986, 211.

20. Sutherland, I. O. Ann. Rep. NMR Spectrosc. 1971, 4, 71.

21. Han, S.-Y.; Kang, M.-H.; Jung, Y.; Chang, S.-K. J. Chem. Soc., Perkin Trans. 2 1994, 835.

22. Hosseini, M. W.; De Cian, A. Chem. Commun. 1998, 727.

23. Ferguson, G.; Gallagher, J. F.; Li, Y.; McKervey, M. A.; Madigan, E.; Malone, J. F.; Moran, M. B.; Walker, A. Supramol. Chem. 1996, 7, 223.

24. Kraft, D.; Böhmer, V.; Vogt, W.; Ferguson, G.; Gallagher, J. F. J. Chem. Soc., Perkin Trans. 1 1994, 1221.

25. Self-inclusion of cyclodextrins, see: Harada, A.; Kawaguchi, Y.; Hoshino, T. J. Inclusion Phenom. Mol. Recognit. Chem. 2001, 41, 115.

26. The signals, attributed to benzyl-, three aromatic-, and carbonyl carbons, were not detected because of low solubility of the calixarene. 